\title{
Functional-Group-Tolerant, Silver-Catalyzed N-N Bond Formation by Nitrene Transfer to Amines
}

Lourdes Maestre, ${ }^{\dagger}$ Ruth Dorel, ${ }^{\ddagger}$ Óscar Pablo, ${ }^{\ddagger}$ Imma Escofet, ${ }^{\ddagger}$ W. M. C. Sameera, ${ }^{\ddagger}{ }^{\ddagger}$ Eleuterio Álvarez,

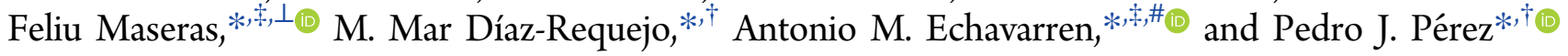

${ }^{\dagger}$ Laboratorio de Catálisis Homogénea, Unidad Asociada al CSIC, CIQSO-Centro de Investigación en Química Sostenible and Departamento de Química, Universidad de Huelva, 21007 Huelva, Spain

${ }^{*}$ Institute of Chemical Research of Catalonia, ICIQ, The Barcelona Institute of Science and Technology, Avgda. Països Catalans, 16, 43007 Tarragona, Spain

${ }^{\S}$ Department of Chemistry, Faculty of Science, Hokkaido University, North-10 West-8 Kita-ku, Sapporo, Hokkaido 060-0810, Japan

"Instituto de Investigaciones Químicas, Centro de Investigaciones Científicas Isla de la Cartuja, CSIC, Avenida Américo Vespucio 49, 41092 Sevilla, Spain

${ }^{\perp}$ Departament de Química, Universitat Autònoma de Barcelona, 08193 Bellaterra, Spain

\#Departament de Química Orgànica i Analítica, Universitat Rovira i Virgili, C/Marcel·lí Domingo s/n, 43007 Tarragona, Spain

Supporting Information

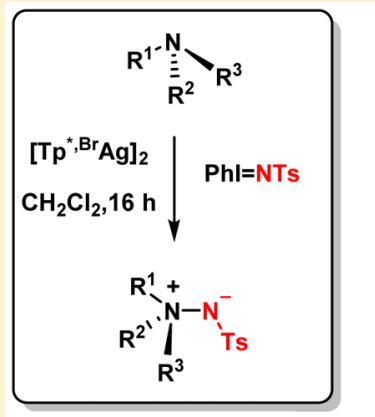

selected examples:

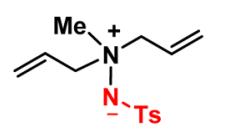

Me

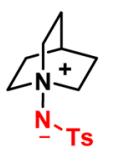

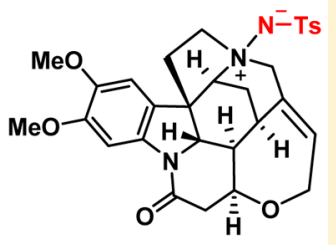

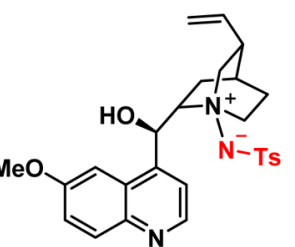

ABSTRACT: Silver(I) promotes the highly chemoselective $N$-amidation of tertiary amines under catalytic conditions to form aminimides by nitrene transfer from $\mathrm{PhI}=\mathrm{NTs}$. Remarkably, this transformation proceeds in a selective manner in the presence of olefins and other functional groups without formation of the commonly observed aziridines or $\mathrm{C}-\mathrm{H}$ insertion products. The methodology can be applied not only to rather simple tertiary amines but also to complex natural molecules such as brucine or quinine, where the products derived from $\mathrm{N}-\mathrm{N}$ bond formation were exclusively formed. Theoretical mechanistic studies have shown that this selective $\mathrm{N}$-amidation reaction proceeds through triplet silver nitrenes.

\section{INTRODUCTION}

Transition-metal-catalyzed nitrene transfer reactions constitute well-established methods for the synthesis of aziridines by functionalization of unsaturated $\mathrm{C}=\mathrm{C}$ bonds ${ }^{1}$ and for the preparation of protected amines by the insertion into saturated $\mathrm{C}-\mathrm{H}$ bonds. ${ }^{1 \mathrm{a}-\mathrm{c}, 2}$ Most of these methods rely on the generation of an active metal-nitrene species from isolated or in situ generated hypervalent iodine reagents ${ }^{3}$ or azides ${ }^{4}$ (Scheme 1).

The nitrene transfer to amines, pyridines, and other aromatic $\mathrm{N}$-heterocycles results in the formation of aminimides of general formula $\mathrm{R}_{3} \mathrm{~N}^{+}-\mathrm{N}^{-} \mathrm{R},{ }^{5,6}$ which display distinctive physicochemical properties due to their zwitterionic nature and consequently have found a wide range of applications ${ }^{6}$ including their use as polymer additives in adhesives ${ }^{8}$ and surfactants. ${ }^{9}$ Aminimides have also been studied as potential CNS-acting agents, ${ }^{10}$ antifungal, ${ }^{11}$ anticancer, ${ }^{12}$ and antiperox-
Scheme 1. General Metal-Catalyzed Nitrene Transfer to Unsaturated or Saturated bonds

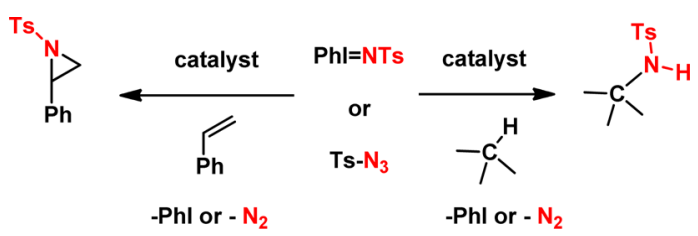

idation agents, ${ }^{13}$ HIV-1 protease inhibitors, ${ }^{14}$ and peptidomimetics. ${ }^{15}$ Furthermore, aminimides have also been used as precursors for the generation of isocyanates ${ }^{16}$ and as

Received: August 7, 2016

Published: January 18, 2017 
intermediates for the synthesis of biologically active imidazolidinones. $^{17}$

Aminimides can be obtained by the thermal reaction of sulfonyl azides with pyridines and amines (Scheme $2 \mathrm{a}$ ), ${ }^{18}$ by

Scheme 2. Methods for the Synthesis of Aminimides

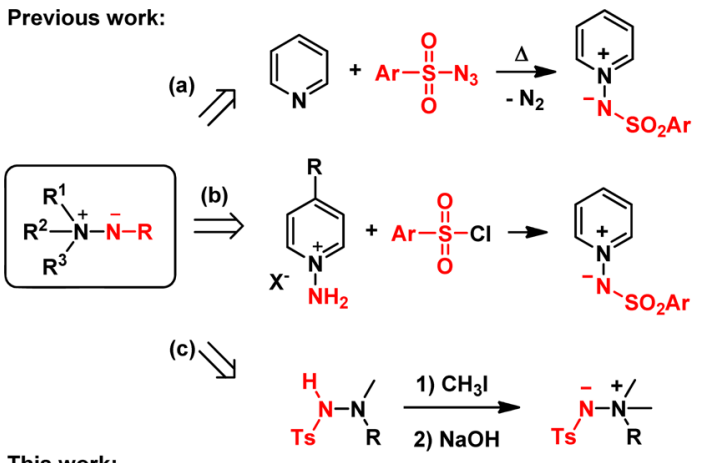

This work:

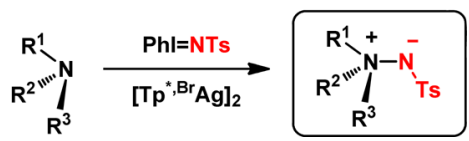

sulfonylation of $N$-amino pyridium salts (Scheme $2 \mathrm{~b}$ ), ${ }^{12,19}$ as well as by quaternization of hydrazine derivatives (Scheme $2 c) .^{20}$ However, many of these synthetic protocols exhibit low selectivity and therefore show a narrow substrate scope or give aminimides in low yields with the concomitant formation of side products from competing reactions. ${ }^{21}$

We have developed group 11 metal-based catalysts for the nitrene transfer reactions to saturated and unsaturated substrates. ${ }^{22-24}$ Furthermore, a general mechanistic profile for the aziridination of olefins catalyzed by $\mathrm{Tp}^{x} \mathrm{M}$ systems $(\mathrm{M}=\mathrm{Cu}$ and $\mathrm{Ag}$ ) based on experimental data and theoretical calculations $^{25}$ has been reported from our laboratories. Stavropoulos and co-workers have also provided related mechanistic studies on copper-based nitrene transfer reactions. $^{26}$ From those contributions, the importance of the electronic states of the metal-nitrene intermediates in the mechanism of these transformations has been demonstrated.

It has also been shown that certain functional groups can exert a significant effect on the catalytic process. Thus, the silver-catalyzed aziridination of dienes bearing a terminal hydroxyl group at the allylic position proceeds in a regio- and stereospecific manner to form vinylaziridines through nitrene transfer to the double bond neighboring to the hydroxyl group (Scheme 3), ${ }^{23}$ which was applied for the synthesis of sphingosine. The high regioselectivity was explained in terms of the directing effect of the hydroxyl group through hydrogen bond with one of the oxygen atoms of the tosyl group of the silver-nitrene intermediate.

With the aim of expanding this methodology, we embarked on the use of allylic amines as the substrates for the metalcatalyzed nitrene transfer reaction. Following this strategy, we have discovered that the NTs moiety is selectively transferred to the amine functionality to form aminimides, even in the presence of a $\mathrm{C}=\mathrm{C}$ bond. This unprecedented observation has been expanded to a number of examples showing a high degree of tolerance with other functional groups. We also provide a mechanistic rationale for this highly chemoselective $\mathrm{N}-\mathrm{N}$ bond formation with the aid of theoretical calculations.
Scheme 3. Silver-Catalyzed Regio- and Stereoselective Aziridination of Dienols
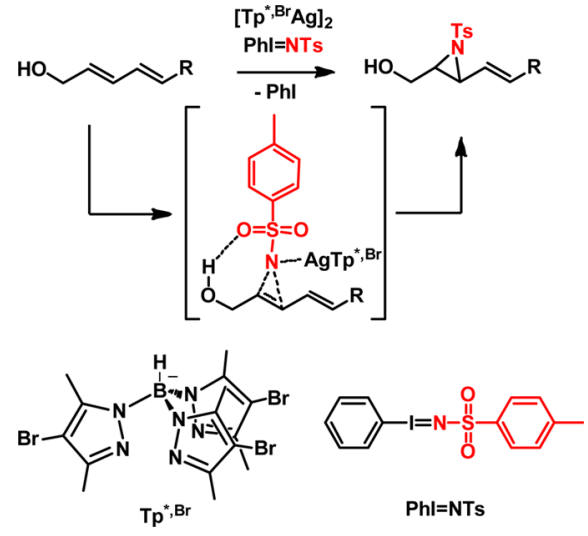

RESULTS AND DISCUSSION

Development of the $\mathrm{N}$-Amidation Reaction and Substrate Scope. We first tried the reaction of allyl amine with $\mathrm{PhI}=\mathrm{NTs}$ in the presence of $\mathrm{Tp}^{\mathrm{Br} 3} \mathrm{Cu}(\mathrm{NCMe})$ or $\left[\mathrm{Tp}{ }^{*}, \mathrm{Br} \mathrm{Ag}\right]_{2}$ as catalysts, ${ }^{27}$ although complex mixtures of products were observed. However, the use of $\mathrm{N}, \mathrm{N}$-dimethylallylamine (1) as the substrate led to the isolation of the aminimide product 2 in $65-76 \%$ yield using both catalysts as the result of the formation of a N-N bond by transfer of the NTs group from the metal center to the amine (Scheme 4a). A

Scheme 4. Silver-Catalyzed Selective Formation of Aminimides

(a)

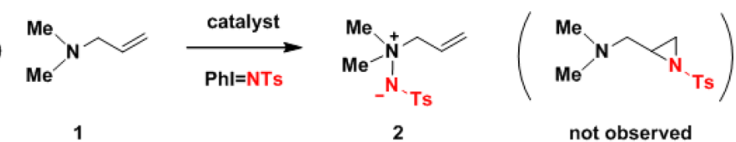

\begin{tabular}{lc} 
catalyst & $2(\%)^{\mathrm{a}}$ \\
\hline $\mathrm{Tp}^{\mathrm{Br} 3} \mathrm{Cu}(\mathrm{NCMe}), 25^{\circ} \mathrm{C}$ & 65 \\
{$\left[\mathrm{Tp}^{*}, \mathrm{Br} \mathrm{Ag}\right]_{2}, 25^{\circ} \mathrm{C}$} & 76 \\
{$\left[\mathrm{Tp}{ }^{*} \mathrm{Br} \mathrm{Ag}\right]_{2}, 50^{\circ} \mathrm{C}$} & $>99(95)^{\mathrm{b}}$ \\
no catalyst & 0
\end{tabular}
not observed no catalyst

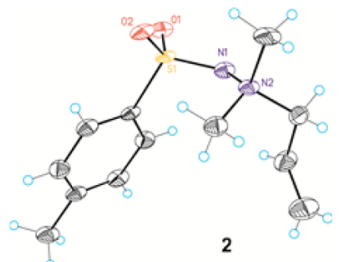

(b)

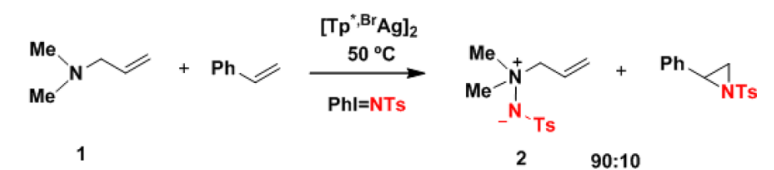

${ }^{a}$ Reaction conditions: [catalyst $] /[\mathrm{PhI}=\mathrm{NTs}] /[$ amine $]=1: 20: 100$ with respect to $0.015 \mathrm{mmol}$ of catalyst. NMR yields. $\mathrm{TsNH}_{2}$ accounted for $100 \%$ initial PhINTs not converted into aminimide $2 .{ }^{b}$ Isolated yield in parentheses. The competition reaction was evaluated by NMR.

minor product, which was also formed in the noncatalyzed reaction of $\mathrm{PhI}=\mathrm{NTs}$ and $\mathbf{1}$ under identical conditions, was detected from the crude reaction mixtures. This product was not stable enough to be isolated, but in any case its formation was circumvented by performing the silver-catalyzed reaction at $50{ }^{\circ} \mathrm{C}$, which led to the isolation of aminimide 2 in almost quantitative yields. It is remarkable that the corresponding aziridine could not be detected in spite of the well-known capabilities of the catalysts employed to promote such $\mathrm{C}=\mathrm{C}$ functionalization. In fact, when a competition experiment with 
equimolar mixtures of $\mathbf{1}$ and styrene was carried out under those optimized conditions, a mixture of $\mathbf{2}$ and the aziridine derived from styrene was obtained in ca. 9:1 ratio (Scheme 4b). Given the well-known tendency of styrene to be aziridinated by this methodology, this result assesses the outstanding selectivity of our catalytic system toward the formation of the $\mathrm{N}-\mathrm{N}$ bond.

The structure of $\mathbf{2}$ was unambiguously assigned by X-ray diffraction (Scheme 4 and Supporting Information), thus confirming the presence of the aminimide moiety with a N$\mathrm{N}$ bond length of $1.467(1) \AA$, which is within the expected range for the dipolar $\mathrm{R}_{3} \mathrm{~N}^{+}-\mathrm{N}^{-} \mathrm{SO}_{2} \mathrm{R}^{\prime}$ nitrogen ylide function ${ }^{28}$

The substrate scope of this transformation was next examined for a series of tertiary amines with a variety of structural motifs and functional groups (Scheme 5). The reactions were carried out in the presence of the silver $\left[\mathrm{Tp}^{*}, \mathrm{Br} \mathrm{Ag}\right]_{2}$ catalyst using an excess of the amine with respect to the nitrene source at room temperature or at $50{ }^{\circ} \mathrm{C}$. In general, good to excellent isolated yields (44-95\%) were obtained for the diverse array of substrates examined. The high tendency of this catalytic system to selectively form $\mathrm{N}-\mathrm{N}$ bonds in the presence of $\mathrm{C}=\mathrm{C}$ bonds is highlighted in the reaction of mono-, di-, and triallyl amines that were cleanly converted into their corresponding aminimides 3-7, which were characterized spectroscopically as well as by X-ray diffraction (Supporting Information). It is worth noting that aminimides 6 and 7 derive from di- and trisubstituted olefins, respectively, which are more reactive than terminal olefins toward electrophilic reagents. A second series of aminimides 8-15 lacking olefin groups were also prepared. Significantly, no competing $\mathrm{C}_{\mathrm{sp}}{ }^{3}-\mathrm{H}$ functionalization was observed even in cases with available benzylic positions or reactive $\mathrm{C}-\mathrm{H}$ bonds adjacent to ethers or acylamino groups. Nitrogen groups protected as carboxamide (10) or carbamate (11 and 12) do not react. It is important to remark that this silver complex has been shown to be competent for the catalytic amidation of alkanes, ${ }^{29}$ which have $\mathrm{C}_{\mathrm{sp}}{ }^{3}-\mathrm{H}$ bonds much less reactive than those present in these substrates.

With the aim of exploring more complex molecules that could challenge the selectivity of the formation of $\mathrm{N}-\mathrm{N}$ bonds with this catalytic system, we targeted brucine (16) and quinine (19a) as the substrates (Scheme 6). Indeed, brucine (16) and cinchonidine (19b), a closer relative of $19 a$, had been studied before as substrates in a rhodium-catalyzed nitrene transfer reaction. $^{21 \mathrm{~b}}$ In that study from other laboratories, 16 gave aminimide $17 \mathrm{a}$ in low yield, together with lactam 18 as a result of a competing $\mathrm{C}-\mathrm{C}$ bond cleavage, whereas in the case of $19 \mathrm{~b}$, the $\mathrm{N}$-amidation occurred unselectively at the quinoclidine and quinoline nitrogen atoms to give a mixture of three products $\mathbf{2 0 a}-\mathbf{c}$. In sharp contrast, our silver-catalyzed nitrene transfer reaction proceeded very cleanly at the tertiary amines of both brucine (16) and quinine (19a) to give aminimides $17 \mathrm{~b}$ and 21 in 83 and $73 \%$ yield, respectively, whose structures were confirmed by X-ray diffraction analysis (Supporting Information). These two examples underscore the exquisite chemoselectivity of this silver-catalyzed transformation, which leads selectively to the formation of a $\mathrm{N}-\mathrm{N}$ bond in molecules containing $\mathrm{C}=\mathrm{C}$ bonds, pyridine-type rings, carboxamides, electron-rich aromatic systems, as well as activated $\mathrm{C}_{\mathrm{sp}}{ }^{3}-\mathrm{H}$ bonds (tertiary, benzylic, or vicinal to heteroatoms). It is worth mentioning that the reaction of allylic amine 2 with $\mathrm{PhI}=\mathrm{NT}$ s in the presence of $\mathrm{Rh}_{2}(\mathrm{OAc})_{4}$ did not induce the formation of aminimides, with decomposition of the nitrene source into unidentified products being observed.
Scheme 5. Scope of the $\mathrm{Tp}{ }^{*, \mathrm{Br}} \mathrm{Ag}$-Catalyzed Synthesis of Aminimides $^{a}$
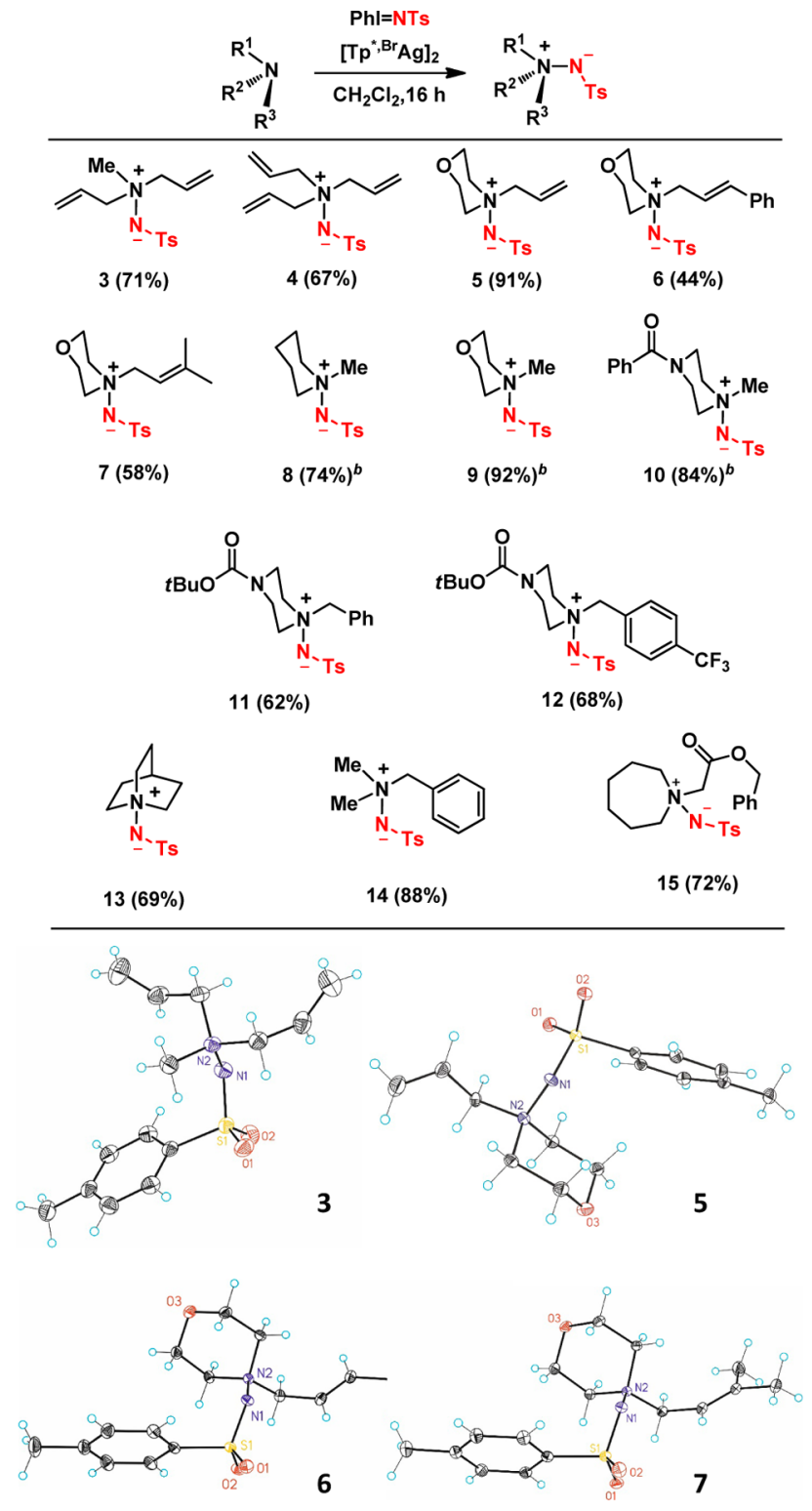

${ }^{a}$ Reaction conditions: [catalyst $] /[\mathrm{PhI}=\mathrm{NTs}] /[$ amine $]=1: 20: 100$ with respect to $0.015 \mathrm{mmol}$ of catalyst (per Ag unit), $6 \mathrm{~mL}$ of $\mathrm{CH}_{2} \mathrm{Cl}_{2}$, reaction temperature $=25{ }^{\circ} \mathrm{C}$. Isolated yields in parentheses. $\mathrm{TsNH}_{2}$ accounted for $100 \%$ initial PhINTs not converted into aminimides. ${ }^{b}$ Reaction carried out at $50{ }^{\circ} \mathrm{C}$. ORTEP plots (50\% thermal ellipsoids) of the X-ray crystal structures of 3 and 5-7 are shown. Atoms are colored as follows: oxygen atoms in red, sulfur atoms in yellow, hydrogen atoms in white, and carbon atoms in gray. See Supporting Information for X-ray crystal structures.

Synthesis of Hydrazines by Thermal Rearrangement of Allylaminimides. Certain allylic and benzylic aminimides are known to undergo thermally induced rearrangements to afford the thermodynamically more stable neutral hydrazide derivatives. ${ }^{30}$ On the basis of these precedents, and in order to evaluate the thermal stability of the aminimides prepared through our method, the rearrangement of 2 was initially examined (Scheme 7). Interestingly, we obtained hydrazone $\mathbf{2 2}$ in an excellent $95 \%$ yield instead of product 23 of allylic migration (Wawzonek rearrangement). ${ }^{30 a}$ Presumably, under 
Scheme 6. Silver-Catalyzed vs Reported RhodiumCatalyzed $^{21 \mathrm{~b}} \mathrm{~N}-\mathrm{N}$ Bond Formation on Complex Natural Products
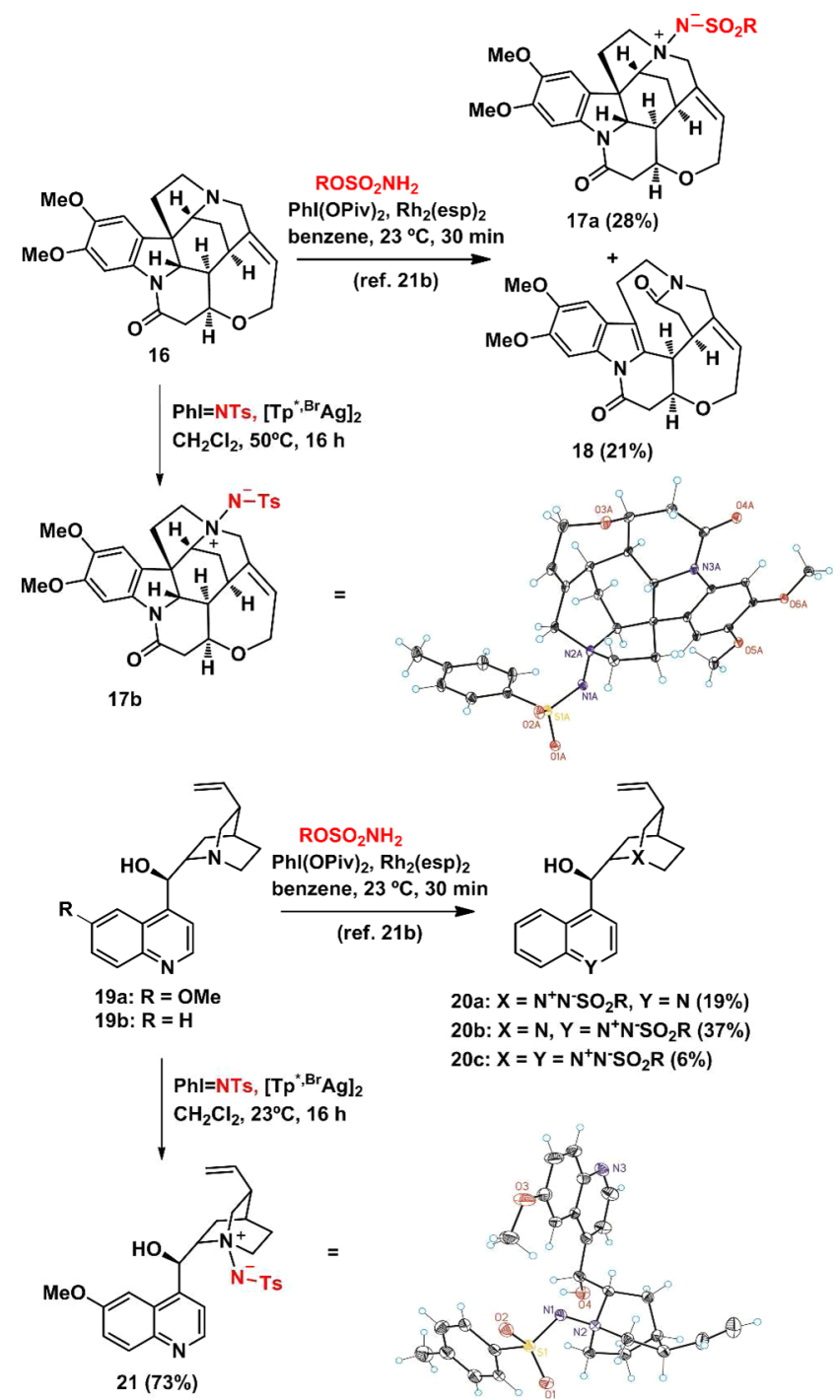

the reaction conditions, initial sulfonyl hydrazine $\mathbf{2 3}$ eliminates $p$-toluenesulphinic acid to form acrolein $\mathrm{N}, \mathrm{N}$-dimethyl hydrazone (24), which then undergoes a Michael-type with $p$-toluenesulphinic acid ${ }^{30 \mathrm{~b}}$ to afford 22. Aminimide 5 underwent an analogous rearrangement to afford crystalline 25, whose structure was confirmed by X-ray diffraction (Supporting Information). In contrast, under the same reaction conditions aminimide 10 gave a complex mixture of products, whereas heating of other aminimides such as $\mathbf{9}$ or $\mathbf{1 4}$ only led to the recovery of unreacted starting materials.

Computational Study on the Origin of the Chemoselectivity. As mentioned above, the reaction described in this contribution is remarkable both because the aminimide is formed and because potential alternative products, namely, aziridines or $\mathrm{C}-\mathrm{H}$ functionalization derivatives, are not. To shed light on the origin of such observance, we first carried out DFT calculations with the M06 functional for the reaction between the parent dimethylallylamine (Sub, 1), $\mathrm{Tp}^{*, \mathrm{Br}} \mathrm{Ag}$ complex, and $\mathrm{PhI}=\mathrm{NTs}$ (the nitrene source). Scheme 8 summarizes the calculated free energy profiles for the $N$ amidation. Starting from the $\left[\mathrm{Tp}^{*, \mathrm{Br}} \mathrm{Ag}\right]_{2}$ system, the $\mathrm{Tp}{ }^{*, \mathrm{Br}} \mathrm{Ag}$
Scheme 7. Thermal Rearrangement of Aminimides 2 and 5

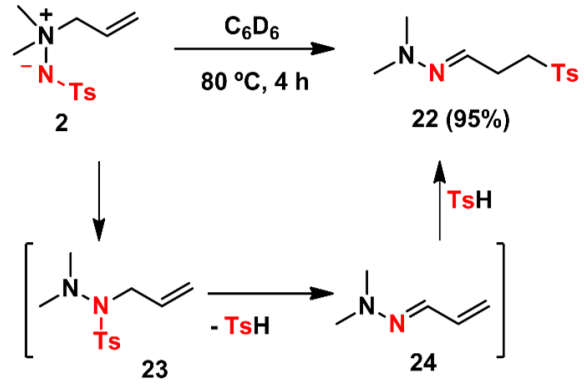

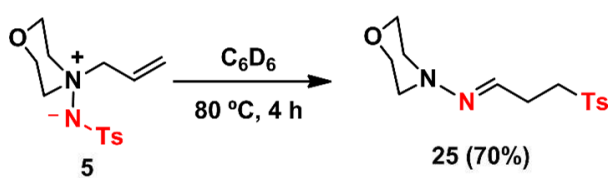

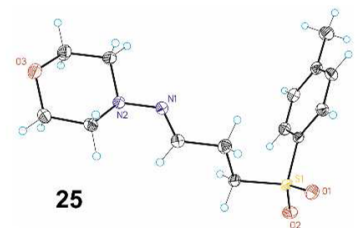

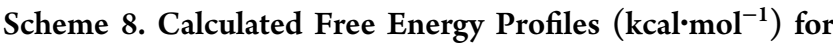
the $N$-Amidation of 1

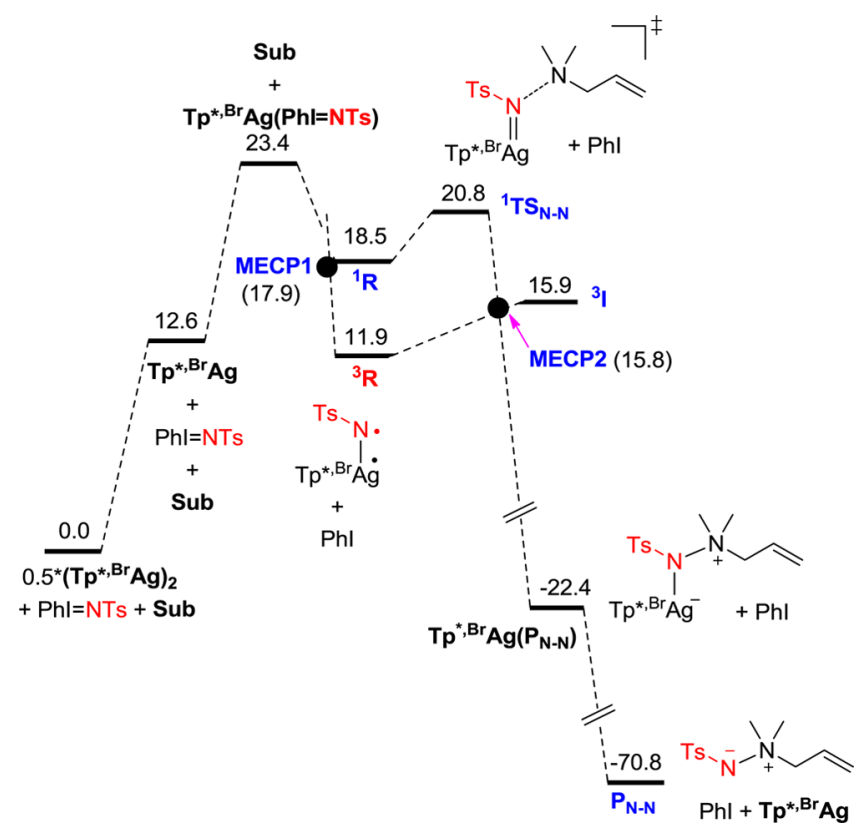

species can be generated with a free energy cost of $12.6 \mathrm{kcal}$ $\mathrm{mol}^{-1}$, in good agreement with previous experimental results. ${ }^{27}$ Then, coordination of $\mathrm{PhI}=\mathrm{NT}$ s gives rise to an intermediate, $\mathrm{Tp}^{*}, \mathrm{Br} \mathrm{Ag}(\mathrm{PhI}=\mathrm{NTs})$, which is further $10.8 \mathrm{kcal} \mathrm{mol}^{-1}$ higher in free energy. This $\mathrm{Tp}^{*}, \mathrm{Br} \mathrm{Ag}(\mathrm{PhI}=\mathrm{NTs})$ intermediate is the highest point in the whole free energy profile, $23.4 \mathrm{kcal} \mathrm{mol}^{-1}$ above the starting species, confirming that once the metalnitrene complex is formed the reaction proceeds smoothly. After dissociation of $\mathrm{PhI}$, the closed-shell singlet state of the metal-nitrene $\left({ }^{1} \mathbf{R}\right)$ can be formed, which is $18.5 \mathrm{kcal} \mathrm{mol}^{-1}$ above the entry point of the free energy profile.

We will first describe the reaction in the above singlet electronic state. Starting from the singlet metal-nitrene 
intermediate $\left({ }^{1} \mathbf{R}\right)$, we located the transition state (TS) for the $\mathrm{N}-\mathrm{N}$ bond formation, which has an overall relative free energy of $20.8 \mathrm{kcal} \mathrm{mol}{ }^{-1}\left({ }^{1} \mathbf{T S}_{\mathrm{N}-\mathrm{N}}\right)$, and leads to the species $\mathrm{Tp}{ }^{*, B r} \operatorname{Ag}\left(\mathbf{P}_{\mathrm{N}-\mathrm{N}}\right)\left(-22.4 \mathrm{kcal} \mathrm{mol}^{-1}\right)$, where the $\mathrm{N}-\mathrm{N}$ bond is already formed. Dissociation of the $\mathbf{P}_{\mathbf{N}-\mathrm{N}}$ product from the catalyst leads to electronic reorganization and a substantial lowering of the free energy down to $-70.8 \mathrm{kcal} \mathrm{mol}^{-1}$. Catalyst $\left(\mathbf{T p}^{*, \mathrm{Br}} \mathbf{A g}\right)$ can be recovered at this point for the next catalytic cycle. The highest free energy point for this singlet path from the nitrene species is ${ }^{1}{ }^{1} S_{\mathrm{N}-\mathrm{N}}$, with a free energy of $20.8 \mathrm{kcal}$ $\mathrm{mol}^{-1}$. There is however a lower energy path through the triplet spin state. The metal-nitrene complex is more stable as a triplet $\left({ }^{3} \mathbf{R}, 11.9 \mathrm{kcal} \mathrm{mol}^{-1},\left\langle S^{2}\right\rangle=2.01\right)$, and this state can be reached through the minimum energy crossing point MECP1 $\left(17.9 \mathrm{kcal} \mathrm{mol}^{-1}\right)$. Spin crossovers in transition metal catalysis are well-known. ${ }^{31}$ The spin density distribution of ${ }^{3} \mathbf{R}[\rho(\mathrm{N})=$ 1.34 an $\rho(\mathrm{Ag})=0.28]$ implies that two unpaired electrons are localized on the metal-nitrene unit. The approach of the substrate to ${ }^{3} \mathbf{R}$ leads to the intermediate $\left({ }^{3} \mathbf{I},\left\langle S^{2}\right\rangle=2.02\right)$, which is $4.0 \mathrm{kcal} \mathrm{mol}^{-1}$ higher in free energy. In ${ }^{3} \mathrm{I}$, the $\mathrm{N}-\mathrm{N}$ bond distance is longer $(2.45 \AA)$, and the calculated spin density distribution in ${ }^{3} \mathrm{I}[\rho(\mathrm{N})=1.30, \rho(\mathrm{Ag})=0.04$, and $\rho(\mathrm{N}$, Sub $)=0.45]$ implies some spin density transfer from the metal-nitrene unit to the substrate. Despite several attempts, we were unable to locate a TS connecting from ${ }^{3} \mathbf{R}$ to ${ }^{3} \mathbf{I}$. We confirmed the absence of a transition state in the potential energy surface by a scan of the approach between the two fragments (Figure S1). We explored the eventual existence of an open-shell singlet state in geometries similar to ${ }^{3} \mathbf{I}$, with all attempts leading to the closed-shell species $\mathbf{T} \mathbf{p}^{*, \mathrm{Br}} \mathbf{A g}\left(\mathbf{P}_{\mathrm{N}-\mathrm{N}}\right)$. Beyond the ${ }^{3} \mathrm{I}$ intermediate, the triplet potential energy surface is highly repulsive (see Figure S1). The key to the triplet reactivity is the existence of a minimum energy crossing point (MECP2, $15.8 \mathrm{kcal} \mathrm{mol}^{-1}$ ), which is very close in geometry to ${ }^{3} \mathbf{I}$, returning to the singlet state. By crossing to the triplet state, the product can be reached through a highest free energy point of $17.9 \mathrm{kcal} \mathrm{mol}^{-1}$ (MECP1) when starting from ${ }^{1} \mathbf{R}$ or through an even lower free energy point of $15.8 \mathrm{kcal} \mathrm{mol}^{-1}$ (MECP2) when starting from ${ }^{3} \mathbf{R}$. These free energies are clearly affordable under the experimental conditions.

We next explored the free energy profiles for the competing aziridination process (Scheme 9). There are number of reports in the literature on the mechanisms of transition metal catalyzed aziridination, showing concerted or radical reaction paths. ${ }^{32}$ The concerted two-electron transfer from ${ }^{1} \mathbf{R}$ to $\mathrm{C}=\mathrm{C}$ of the substrate can occur through the closed-shell singlet TS $\left({ }^{1} \mathrm{TS}_{\mathrm{N}-\mathrm{C}}, 25.3 \mathrm{kcal} \mathrm{mol}^{-1}\right)$, giving rise to the $\mathbf{T} \mathbf{p}^{*, \mathrm{Br}} \mathbf{A g}\left(\mathbf{P}_{\mathrm{C}-\mathrm{N}}\right)$ complex $\left(-45.2 \mathrm{kcal} \mathrm{mol}^{-1}\right)$. Despite several attempts, location of the corresponding open-shell form of the TS was not successful, where calculations ultimately converged to the product complex, $\mathbf{T} \mathbf{p}^{*, B r} \mathbf{A g}\left(\mathbf{P}_{\mathrm{C}-\mathrm{N}}\right)$. The stepwise two-electron transfer from the thermodynamically stable ${ }^{3} \mathbf{R}$ can occur through the triplet TS $\left({ }^{3} \mathrm{TS}_{\mathrm{N}-\mathrm{C}}, 21.2 \mathrm{kcal} \mathrm{mol}^{-1}\right)$, with the first electron transfer leading to $\mathrm{N}-\mathrm{C} 1$ bond formation and a triplet radical intermediate ${ }^{3} \mathrm{RI}$ formed $\left(1.3 \mathrm{kcal} \mathrm{mol}^{-1}\right)$. We have also located the barrier for the $\mathrm{N}-\mathrm{C} 2$ bond formation, which is however $3.4 \mathrm{kcal} \mathrm{mol}^{-1}$ higher than ${ }^{3} \mathrm{TS}_{\mathrm{N}-\mathrm{C}}$ (not shown in Scheme 9). Before ${ }^{3} \mathbf{R I}$, there is a MECP between the triplet and singlet surfaces complex (MECP3, $0.3 \mathrm{kcal} \mathrm{mol}^{-1}$, leading to the $\mathbf{T} \mathbf{p}^{*, B r} \operatorname{Ag}\left(\mathbf{P}_{\mathbf{C}-\mathrm{N}}\right)$. Then, the aziridine product, $\mathbf{P}_{\mathbf{C}-\mathbf{N}}$ $\left(-95.5 \mathrm{kcal} \mathrm{mol}^{-1}\right)$, dissociates from the metal center. The overall picture of the free energy profiles for the aziridination is consistent with our previous reports. ${ }^{23 b, 25}$

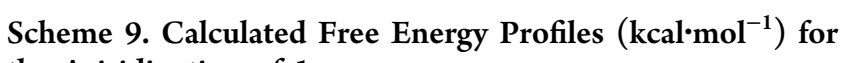
the Aziridination of 1

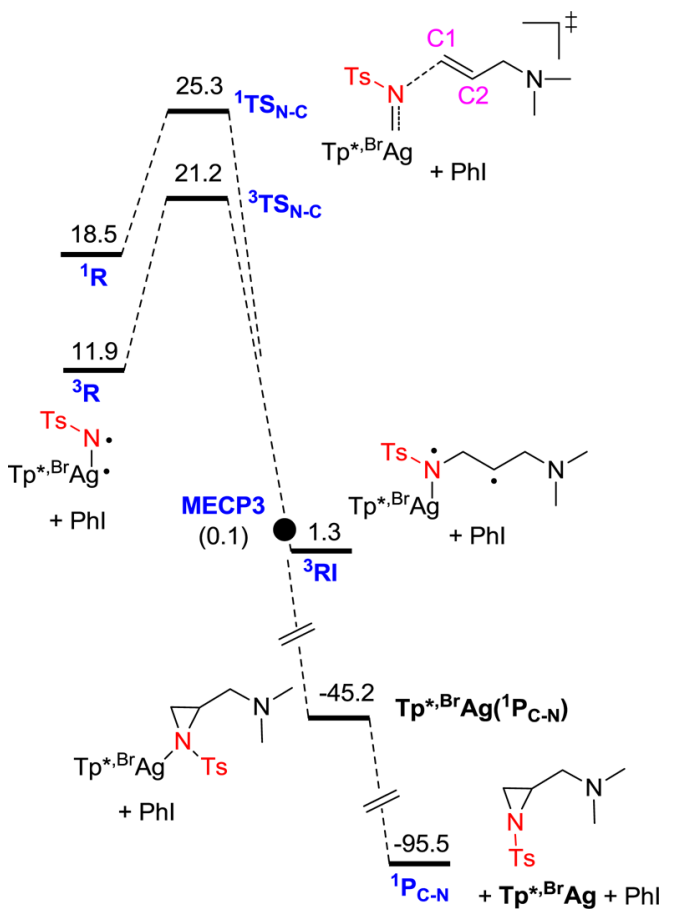

The $\mathrm{N}-\mathrm{N}$ bond formation could start from the triplet metal-nitrene intermediate $\left({ }^{3} \mathbf{R}\right)$, since this step only requires $3.9 \mathrm{kcal} \mathrm{mol}^{-1}$ barrier (MECP2). The alternative aziridination pathway from ${ }^{3} \mathbf{R}$ is less likely to occur, since the barrier $\left({ }^{3} \mathrm{TS}_{\mathrm{N}-\mathrm{C}}\right)$ for this process is significantly higher $(9.3 \mathrm{kcal}$ $\left.\mathrm{mol}^{-1}\right)$. This is in agreement with our experimental results. Additionally, NMR studies have shown that there is no direct interaction between the silver complex and the amine substrate. The aziridination is certainly favored thermodynamically but kinetically disfavored. Similar conclusions can be made from M06L and $\omega$ B97XD free energy profiles (Figures S2 and S3), where energy separations between MECP2 and ${ }^{3} \mathrm{TS}_{\mathrm{N}-\mathrm{C}}$ are 6.0 and $5.0 \mathrm{kcal} \mathrm{mol}^{-1}$, respectively. According to these results, we conclude that the $\mathrm{N}-\mathrm{N}$ bond formation is favored over the aziridination.

The calculations reported above involve a number of approximations due to the size and complexity of the system. We comment here on two of them that we consider may affect specific numbers but would not alter the general trends. The free energy profiles could be refined to take into account the presence of diffusion barriers in the barrierless steps (or those with very low barrier) in the potential energy surface (for instance from ${ }^{3} \mathbf{R}$ to ${ }^{3} \mathbf{I}$ ), a procedure that has been applied in other cases. ${ }^{33}$ However, this would have a similar effect on both competing pathways, resulting in the same balance. Another issue is the assumption that the spin flip between different spin states will take place easily once the MECP is reached. We suspect this is the case, although we have not proved it through computationally demanding spin-orbit coupling calculations. We would like in any case to mention that the trend would be the same if the systems stayed in the singlet state throughout the process, as the singlet/triplet difference is similar for both pathways.

The efficiency of the formation of the aminimide can be explained by the combination of two factors: (i) The nitrogen 
lone pair is more nucleophilic than the $\pi$-electrons of the $\mathrm{C}-\mathrm{C}$ double bond. (ii) The aminimide formation from the high energy metal-nitrene complex is sufficiently exergonic to make the reaction irreversible. The combination of the two factors leads to the exceptional selectivity of this system.

\section{CONCLUSIONS}

The chemoselective $N$-amidation of tertiary amines catalyzed by a $\mathrm{Ag}(\mathrm{I})$ complex has been developed using $\mathrm{PhI}=\mathrm{NT}$ s as the nitrene source, thus opening a new entry to the synthesis of functionalized aminimides. This transformation tolerates a range of functionalities including aromatic $N$-heterocycles and olefins, which remain unreacted under the reaction conditions. Complex natural products such as brucine and quinine have been selectively functionalized at the tertiary amine site, in spite of the presence of other functional groups, including olefins or allylic $\mathrm{C}-\mathrm{H}$ bonds. The selectivity of the process has been rationalized by DFT calculations.

\section{EXPERIMENTAL SECTION}

General Methods. Reactions under inert (argon or nitrogen) atmosphere were carried out in solvents dried by passing through an activated alumina column on a PureSolv solvent purification system (Innovative Technologies, Inc., MA). Analytical thin layer chromatography was carried out using TLC-aluminum sheets with $0.2 \mathrm{~mm}$ of silica gel $\left(\right.$ Merck $\left.\mathrm{GF}_{234}\right)$ using UV light as the visualizing agent and an acidic solution of vanillin in ethanol as the developing agent. Chromatographic purifications were carried out using flash-grade silica gel (SDS Chromatogel 60 ACC, 40-63 $\mu \mathrm{m}$ ). Organic solutions were concentrated under reduced pressure on a Büchi rotary evaporator. All reagents were used as purchased and used with no further purification. $\mathrm{PhI}=\mathrm{NTs}^{34}$ and $\operatorname{Tp}^{x} \mathrm{M}(\mathrm{M}=\mathrm{Cu} \text { and } \mathrm{Ag})^{29,35}$ complexes were prepared according to the procedures described in the literature.

NMR spectra were recorded at $25{ }^{\circ} \mathrm{C}$ on a Fourier 300, Bruker Avance 400 Ultrashield or Bruker Avance 500 Ultrashield apparatus. The signals are given as $\delta(\mathrm{ppm})$ downfield from tetramethylsilane, with calibration on the residual protio-solvent used $(\delta \mathrm{H}=7.26 \mathrm{ppm}$ and $\delta \mathrm{C}=77.00 \mathrm{ppm}$ for $\mathrm{CDCl}_{3}, \delta \mathrm{H}=3.31 \mathrm{ppm}$ and $\delta \mathrm{C}=49.00 \mathrm{ppm}$ for $\mathrm{CD}_{3} \mathrm{OD}$, and $\delta \mathrm{H}=7.16 \mathrm{ppm}$ and $\delta \mathrm{C}=128.06 \mathrm{ppm}$ for $\mathrm{C}_{6} \mathrm{D}_{6}$ ). Mass spectra were recorded on a Waters LCT Premier Spectrometer (ESI and APCI) or on an Autoflex Bruker Daltonics (MALDI and LDI). Melting points were determined using a Büchi melting point apparatus.

Crystal structure determinations were carried out using a BrukerNonius diffractometer equipped with an APPEX 2 4K CCD area detector, a FR591 rotating anode with Mo $\mathrm{K} \alpha$ radiation, Montel mirrors as monochromator, and a Kryoflex low temperature device ( $T$ $\left.=-173{ }^{\circ} \mathrm{C}\right)$. Full-sphere data collection was used with $\mathrm{w}$ and $\mathrm{j}$ scans. Programs used: Data collection, APEX-2, data reduction, Bruker Saint V.60A, and absorption correction, SADABS.

Structure Solution and Refinement. Crystal structure solutions were achieved using direct methods as implemented in SHELXTL and visualized using the program XP. Missing atoms were subsequently located from difference Fourier synthesis and added to the atom list. Least-squares refinement on $F^{2}$ using all measured intensities was carried out using the program SHELXTL. All non-hydrogen atoms were refined including anisotropic displacement parameters.

General Procedure for the Synthesis of Aminimides. A previously flame-dried Schlenk covered with aluminum foil was charged with $\left[\mathrm{Tp}^{*, \mathrm{Br}} \mathrm{Ag}\right]_{2}(0.0075 \mathrm{mmol})$ and a magnetic stirring bar inside a glovebox before being equipped with a septum. Dry and degassed $\mathrm{CH}_{2} \mathrm{Cl}_{2}(6 \mathrm{~mL})$ was added followed by the corresponding amine $(1.5 \mathrm{mmol})$. After stirring for $5 \mathrm{~min}, \mathrm{PhI}=\mathrm{NTs}(0.3 \mathrm{mmol})$ was added in one portion to the reaction, and the mixture was stirred for $16 \mathrm{~h}$ at the desired temperature. Then, volatiles were removed under reduced pressure and the resulting crude was purified by silica gel column chromatography unless otherwise stated. See Supporting Information for details and full spectroscopic data.

Rearrangement of Allylaminimides. A microwave vial was charged with the corresponding aminimide $(0.1 \mathrm{mmol})$ and a magnetic stirring bar. The tube was equipped with a septum and evacuated and backfilled with $\operatorname{Ar}$ (3 times). Then, $\mathrm{C}_{6} \mathrm{D}_{6}(2 \mathrm{~mL})$ was added, and the reaction was heated up to $80{ }^{\circ} \mathrm{C}$ during $4 \mathrm{~h}$ (monitored by ${ }^{1} \mathrm{H}$ NMR). After cooling down to room temperature, the volatiles were removed under reduced pressure to obtain crude hydrazine. See Supporting Information for purification details and full spectroscopic data.

Computational Details. Solvent-phase structure optimizations were performed with the M06 density functional, ${ }^{36}$ as implemented in Gaussian09 program. ${ }^{37}$ The SMD implicit solvation model was used with dichloromethane $(\varepsilon=8.93)$. The SDD basis sets were used for silver, copper, bromine, and iodine. ${ }^{38}$ The $6-31 \mathrm{G}(\mathrm{d})$ basis sets were used for the remaining atoms. ${ }^{39}$ Final energies were obtained by doing single-point energy calculations on the optimized structures, where silver, bromine, and iodine were still described with SDD, while the remaining atoms were treated with the $6-311++G(d, p)$ basis sets. All geometry optimizations were full with no restrictions, and vibrational frequency calculations were performed to establish the nature of the stationary points (i.e., minima or transition states). Connectivity of the transition states was confirmed by IRC calculations. Free-energy corrections at $298.15 \mathrm{~K}$ and $1 \mathrm{~atm}$ pressure were used, including zeropoint energy corrections. Minimum energy crossing points were calculated by using the MECP program of J. N. Harvey and coworkers. ${ }^{40}$ Thermal corrections to the MECP structures were obtained by performing frequency calculations for the two states and taking the average values of the corrections. The M06 functional applied here was found in previous works on aziridination by related systems to perform better than BP86. ${ }^{23 \mathrm{~b}, 25}$ We have further benchmarked its performance by repeating selecting calculations with the M06 $\mathrm{L}^{36}$ and $\omega \mathrm{B} 97 \mathrm{XD}^{41}$ functionals and found very similar results (see Supporting Information). The eventual existence of open-shell singlet electronic states was evaluated through stability calculations ${ }^{42}$ on the selected species ${ }^{1} \mathbf{R},{ }^{1} \mathbf{T S}_{\mathrm{N}-\mathrm{N}}$, and ${ }^{1} \mathbf{T S}_{\mathrm{N}-\mathrm{C}}$. In all cases, it was found that the closed-shell singlet was preferred.

\section{ASSOCIATED CONTENT}

\section{S Supporting Information}

The Supporting Information is available free of charge on the ACS Publications website at DOI: 10.1021/jacs.6b08219.

All procedures and characterization data for new compounds, computed free energy scan beyond intermediate ${ }^{3} \mathbf{I}$, and Cartesian coordinates of the optimized structures (PDF)

Crystallographic information file for compound 2 (CIF) Crystallographic information file for compound 3 (CIF) Crystallographic information file for compound $\mathbf{5}$ (CIF) Crystallographic information file for compound 6 (CIF) Crystallographic information file for compound 7 (CIF) Crystallographic information file for compound $\mathbf{1 7 b}$ Crystallographic information file for compounds $\mathbf{2 1}$ and 25 (CIF)

\section{AUTHOR INFORMATION}

\section{Corresponding Authors}

*fmaseras@iciq.es

*mmdiaz@dqcm.uhu.es

*aechavarren@iciq.es

*perez@dqcm.uhu.es

ORCID ${ }^{\circ}$

Feliu Maseras: 0000-0001-8806-2019

Antonio M. Echavarren: 0000-0001-6808-3007

Pedro J. Pérez: 0000-0002-6899-4641 


\section{Notes}

The authors declare no competing financial interest.

\section{ACKNOWLEDGMENTS}

We thank MINECO for Grants CTQ2014-52769-C3-1-R, CTQ2013-42106-P, CTQ2014-57761-R, Severo Ochoa Excellence Accreditation 2014-2018 (SEV-2013-0319), Red Intecat (CTQ2014-52974-REDC), FPI fellowship (L.M.), the European Research Council (Advanced Grant No. 321066), the AGAUR (2014 SGR 818), and CERCA Program/Generalitat de Catalunya. We also thank Dr. Tania Jiménez for additional experiments and the ICIQ X-ray diffraction unit for the crystal structures of compounds 5-7, 17b, 21, and 25 .

\section{REFERENCES}

(1) (a) Degennaro, L.; Trinchera, P.; Luisi, R. Chem. Rev. 2014, 114, 7881-7929. (b) Chang, J. W. W.; Ton, T. M. U.; Chan, P. W. H. Chem. Rec. 2011, 11, 331-357. (c) Pellissier, H. Tetrahedron 2010, 66, 1509-1555. (d) Halfen, J. A. Curr. Org. Chem. 2005, 9, 657-669. (e) Müller, P.; Fruit, C. Chem. Rev. 2003, 103, 2905-2919.

(2) (a) Buendía, J.; Grelier, G.; Dauban, P. Adv. Organomet. Chem. 2015, 64, 77-118. (b) Dequirez, G.; Pons, V.; Dauban, P. Angew. Chem., Int. Ed. 2012, 51, 7384-7395. (c) Díaz-Requejo, M. M.; Caballero, A.; Fructos, M. R.; Pérez, P. J. Alkane $\mathrm{C}-\mathrm{H}$ Activation by Single-Site Metal Catalysis; Springer: Amsterdam, 2012; Chapter 6. (d) Zalatan, D. N.; Du Bois, J. Top. Curr. Chem. 2009, 292, 347-378. (f) Díaz-Requejo, M. M.; Pérez, P. J. Chem. Rev. 2008, 108, 33793394.

(3) Sördergren, M. J.; Alonso, D. A.; Bedekar, A. V.; Andersson, P. G. Tetrahedron Lett. 1997, 38, 6897-6900.

(4) Cenini, S.; La Monica, G. Inorg. Chim. Acta 1976, 18, 279-293. (5) (a) Jain, S. L.; Sharma, V. B.; Sain, B. Tetrahedron Lett. 2003, 44, 4385-4387. (b) Ochiai, M.; Kawano, Y.; Kaneaki, T.; Tada, N.; Miyamoto, K. Org. Lett. 2009, 11, 281-284. (c) Ochiai, M.; Miyamoto, K.; Hayashi, S.; Nakanishi, W. Chem. Commun. 2010, 46, 511-521. (d) Pujari, S. A.; Guénée, L.; Lacour, J. Org. Lett. 2013, 15, 3930-3933.

(6) (a) McKillip, W. J.; Sedor, E. A.; Culbertson, B. M.; Wawzonek, S. Chem. Rev. 1973, 73, 255-281. (b) Rademacher, P. Science of Synthesis 2008, 40b, 1133-1210.

(7) (a) Illien, B.; Berthelot, M.; Morris, D. G.; Laurence, C. J. Phys. Org. Chem. 2000, 13, 293-299. (b) Chardin, A.; Laurence, C.; Berthelot, M.; Morris, D. G. J. Chem. Soc., Perkin Trans. 2 1996, 10471051.

(8) Throckmorton, P. E.; Luckman, E. R. Rubber Chem. Technol. 1980, 53, 270-284.

(9) Oba, G.; Coleman, B. E.; Hart, D. J.; Zakin, J.; Zhang, Y.; Kawaguchi, Y.; Talmon, Y. Tetrahedron 2006, 62, 10193-10201.

(10) Capuano, B.; Crosby, I. T.; Lloyd, E. J.; Neve, J. E.; Taylor, D. A. Aust. J. Chem. 2008, 61, 422-431.

(11) Abel, M. D.; Hewgill, R. T.; Malczyk, K. J.; Micetich, R. G.; Daneshtalab, M. J. Heterocycl. Chem. 1998, 35, 193-199.

(12) Gangapuram, M.; Redda, K. K. J. Heterocycl. Chem. 2009, 46, 309-316.

(13) Grisar, J. M.; Marciniak, G.; Bolkenius, F. N.; Verne-Mismer, J.; Wagner, E. R. J. Med. Chem. 1995, 38, 2880-2886.

(14) Rutenber, E. E.; McPhee, F.; Kaplan, A. P.; Gallion, S. L.; Hogan, J. C., Jr.; Craik, C. S.; Stroud, R. M. Bioorg. Med. Chem. 1996, 4, 1545-1558.

(15) Peisach, E.; Casebier, D.; Gallion, S. L.; Furth, P.; Petsko, G.; Hogan, J. C., Jr.; Ringe, D. Science 1995, 269, 66-69.

(16) Kirino, M.; Tomita, I. Macromolecules 2010, 43, 8821-8827.

(17) (a) Aelony, D.; McKillip, W. J. J. Heterocycl. Chem. 1972, 9, 687-690. (b) Wright, W.; Brabander, H.; Hardy, R; Osterberg, A. J. Med. Chem. 1966, 9, 852-857.
(18) (a) Hafner, K.; Zinser, D.; Moritz, K.-L. Tetrahedron Lett. 1964, 5, 1733-1737. (b) Abramovitch, R. A.; Takaya, T. J. Org. Chem. 1972, $37,2022-2029$.

(19) (a) Slagel, R. C. J. Org. Chem. 1968, 33, 1374-1378. (b) Gangapuram, M.; Redda, K. K. J. Heterocycl. Chem. 2009, 46, 309-316. (c) Gangapuram, M.; Mazzio, E.; Eyunni, S.; Soliman, K. F. A.; Redda, K. K. Arch. Pharm. 2014, 347, 360-369.

(20) For selected examples see: (a) Wawzonek, S.; Meyer, D. J. Am. Chem. Soc. 1954, 76, 2918-2920. (b) McKillip, W. J.; Clemens, L. M.; Haugland, R. Can. J. Chem. 1967, 45, 2613-2617. (c) McKillip, W. J.; Slagel, R. C. Can. J. Chem. 1967, 45, 2619-2623. (d) Slagel, R. C.; Bloomquist, A. E. Can. J. Chem. 1967, 45, 2625-2628.

(21) (a) Trost, B. M.; O'Boyle, B. M.; Torres, W.; Ameriks, M. K. Chem. - Eur. J. 2011, 17, 7890-7903. (b) Li, J.; Cisar, J. S.; Zhou, C.Y.; Vera, B.; Williams, H.; Rodríguez, A. D.; Cravatt, B. F.; Romo, D. Nat. Chem. 2013, 5, 510-517.

(22) (a) Pérez, P. J.; Brookhart, M.; Templeton, J. L. Organometallics 1993, 12, 261-262. (b) Díaz-Requejo, M. M.; Pérez, P. J.; Brookhart, M.; Templeton, J. L. Organometallics 1997, 16, 4399-4402. (c) DíazRequejo, M. M.; Belderraín, T. R.; Nicasio, M. C.; Trofimenko, S.; Pérez, P. J. J. Am. Chem. Soc. 2003, 125, 12078-12079. (d) Mairena, M. A.; Díaz-Requejo, M. M.; Belderraín, T.; Nicasio, M. C.; Trofimenko, S.; Pérez, P. J. Organometallics 2004, 23, 253-256. (e) Arenas, I.; Fuentes, M. Á.; Álvarez, E.; Díaz, Y.; Caballero, A.; Castillón, S.; Pérez, P. J. Inorg. Chem. 2014, 53, 3991-3999.

(23) (a) Llavería, J.; Beltrán, A.; Díaz-Requejo, M. M.; Matheu, M. I.; Castillón, S.; Pérez, P. J. Angew. Chem., Int. Ed. 2010, 49, 7092-7095. (b) Llavería, J.; Beltrán, A.; Sameera, W. M. C.; Locati, A.; DíazRequejo, M. M.; Matheu, M. I.; Castillón, S.; Maseras, F.; Pérez, P. J. J. Am. Chem. Soc. 2014, 136, 5342-5350.

(24) (a) Fructos, M. R.; Álvarez, E.; Díaz-Requejo, M. M.; Pérez, P. J. J. Am. Chem. Soc. 2010, 132, 4600-4607. (b) Maestre, L.; Fructos, M. R; Díaz-Requejo, M. M.; Pérez, P. J. Organometallics 2012, 31, 78397843.

(25) Maestre, L.; Sameera, W. M. C.; Díaz-Requejo, M. M.; Maseras, F.; Pérez, P. J. J. Am. Chem. Soc. 2013, 135, 1338-1348.

(26) Bagchi, V.; Paraskevopoulou, P.; Das, P.; Chi, L.; Wang, Q.; Choudhury, A.; Mathieson, J. S.; Cronin, L.; Pardue, D. B.; Cundari, T. R.; Mitrikas, G.; Sanakis, Y.; Stavropoulos, P. J. Am. Chem. Soc. 2014, $136,11362-11381$.

(27) The dinuclear structure of complex $\left[\mathrm{Tp}^{*, \mathrm{Br}} \mathrm{Ag}\right]_{2}$ in the solid state dissociates in solution, as demonstrated by studies of molecular weight in solution. See: Urbano, J.; Braga, A. A.C.; Maseras, F.; Álvarez, E.; Díaz-Requejo, M. M.; Pérez, P. J. Organometallics 2009, 28, 5968-5981.

(28) Morris, D. G.; Ryder, K. S.; Muir, K. W. Cryst. Growth Des. 2005, 5, 361-364.

(29) Gómez-Emeterio, B. P.; Urbano, J.; Díaz-Requejo, M. M.; Pérez, P. J. Organometallics 2008, 27, 4126-4130.

(30) (a) Wawzonek, S.; Yeakey, E. J. Am. Chem. Soc. 1960, 82, 57185721. (b) Baldwin, J. E.; Brown, J. E. J. Org. Chem. 1971, 36, 36423644.

(31) (a) Meunier, P.; de Visser, S. P.; Shaik, S. Chem. Rev. 2004, 104, 3947-3980. (b) Shaik, S.; Kumar, D.; de Visser, S. P.; Altun, A.; Thiel, W. Chem. Rev. 2005, 105, 2279-2328. (c) Schröder, D.; Shaik, S.; Schwarz, H. Acc. Chem. Res. 2000, 33, 139-145. (d) Linde, C.; Akermark, B.; Norrby, P.-O.; Svensson, M. J. Am. Chem. Soc. 1999, 121, 5083-5084. (e) Cavallo, L.; Jacobsen, H. Angew. Chem., Int. Ed. 2000, 39, 589-592. (f) Cavallo, L.; Jacobsen, H. Eur. J. Inorg. Chem. 2003, 2003, 892-902. (g) Cavallo, L.; Jacobsen, H. J. Phys. Chem. A 2003, 107, 5466-5471. (h) Cavallo, L.; Jacobsen, H. J. Org. Chem. 2003, 68, 6202-6207. (h) Jacobsen, H.; Cavallo, L. Chem. - Eur. J. 2001, 7, 800-807.

(32) (a) Comba, P.; Haaf, C.; Lienke, A.; Muruganantham, A.; Wadepohl, H. Chem. - Eur. J. 2009, 15, 10880-10887. (b) Comba, P.; Lang, C.; López de Laorden, C.; Muruganantham, A.; Rajaraman, G.; Wadepohl, H.; Zajaczkowski, M. Chem. - Eur. J. 2008, 14, 5313-5328. (c) Gillespie, K. M.; Crust, E. J.; Deeth, R. J.; Scott, P. Chem. Commun. 2001, 785-786. (d) Brandt, P.; Södergren, M. J.; Andersson, P. G.; 
Norrby, P.-O. J. Am. Chem. Soc. 2000, 122, 8013-8020. (e) Lin, X.; Che, C.-M.; Phillips, D. L. J. Org. Chem. 2008, 73, 529-537. (f) Olivos Suárez, A. I. O.; Jiang, H.; Zhang, X. P.; de Bruin, B. Dalton Trans. 2011, 40, 5697-5705. (g) Cundari, T. R.; Dinescu, A.; Kazi, A. B. Inorg. Chem. 2008, 47, 10067-10072. (h) Hopmann, K. H.; Ghosh, A. ACS Catal. 2011, 1, 597-600. (i) Kundu, S.; Miceli, E.; Farquhar, E.; Pfaff, F. F.; Kuhlmann, U.; Hildebrandt, P.; Braun, B.; Greco, C.; Ray, C. J. Am. Chem. Soc. 2012, 134, 14710-14713. (j) Lyaskovskyy, V.; Suarez, A. I. O.; Lu, H.; Jiang, H.; Zhang, X. P.; de Bruin, B. J. Am. Chem. Soc. 2011, 133, 12264-12273. (k) Klotz, K. L.; Slominski, L. M.; Riemer, M. E.; Phillips, J. A.; Halfen, J. A. Inorg. Chem. 2009, 48, 801-803.

(33) (a) Rush, L. E.; Pringle, P. G.; Harvey, J. N. Angew. Chem., Int. Ed. 2014, 53, 8672-8676. (b) Goehry, C.; Besora, M.; Maseras, F. ACS Catal. 2015, 5, 2445-2451. (c) Fernández-Alvarez, V. M.; Nappi, M.; Melchiorre, P.; Maseras, F. Org. Lett. 2015, 17, 2676-2679.

(34) Yamada, Y.; Yamamoto, T.; Okawara, M. Chem. Lett. 1975, 4, $361-362$.

(35) Caballero, A.; Díaz-Requejo, M. M.; Belderrain, T. R.; Nicasio, M. C.; Trofimenko, S.; Pérez, P. J. J. Am. Chem. Soc. 2003, 125, 14461447.

(36) Zhao, Y.; Truhlar, D. G. J. Chem. Phys. 2006, 125, 194101194118.

(37) Frisch, M. J.; Trucks, G. W.; Schlegel, H. B.; Scuseria, G. E.; Robb, M. A.; Cheeseman, J. R.; Scalmani, G.; Barone, V.; Mennucci, B.; Petersson, G. A.; Nakatsuji, H.; Caricato, M.; Li, X.; Hratchian, H. P.; Izmaylov, A. F.; Bloino, J.; Zheng, G.; Sonnenberg, J. L.; Hada, M.; Ehara, M.; Toyota, K.; Fukuda, R.; Hasegawa, J.; Ishida, M.; Nakajima, T.; Honda, Y.; Kitao, O.; Nakai, H.; Vreven, T.; Montgomery, J. A., Jr.; Peralta, J. E.; Ogliaro, F.; Bearpark, M.; Heyd, J. J.; Brothers, E.; Kudin, K. N.; Staroverov, V. N.; Kobayashi, R.; Normand, J.; Raghavachari, K.; Rendell, A.; Burant, J. C.; Iyengar, S. S.; Tomasi, J.; Cossi, M.; Rega, N.; Millam, J. M.; Klene, M.; Knox, J. E.; Cross, J. B.; Bakken, V.; Adamo, C.; Jaramillo, J.; Gomperts, R.; Stratmann, R. E.; Yazyev, O.; Austin, A. J.; Cammi, R.; Pomelli, C.; Ochterski, J. W.; Martin, R. L.; Morokuma, K.; Zakrzewski, V. G.; Voth, G. A.; Salvador, P.; Dannenberg, J. J.; Dapprich, S.; Daniels, A. D.; Farkas, O.; Foresman, J. B.; Ortiz, J. V.; Cioslowski, J.; Fox, D. J. Gaussian 09, revision B.01; Gaussian, Inc.: Wallingford, CT, 2009.

(38) Andrae, D.; Häussermann, U.; Dolg, M.; Stoll, H.; Preuss, H. Theor. Chim. Acta 1990, 77, 123-141.

(39) (a) Hehre, W. J.; Ditchfield, R.; Pople, J. A. J. Chem. Phys. 1972, 56, 2257-2261. (b) Hariharan, P. C.; Pople, J. A. Theor. Chim. Acta 1973, 28, 213-222. (c) Gordon, M. S. Chem. Phys. Lett. 1980, 76, $163-168$.

(40) Harvey, J. N.; Aschi, M.; Schwarz, H.; Koch, W. Theor. Chem. Acc. 1998, 99, 95-99.

(41) Chai, J.-D.; Head-Gordon, M. Phys. Chem. Chem. Phys. 2008, 10, 6615-6620.

(42) Bauernschmitt, R.; Ahlrichs, R. J. Chem. Phys. 1996, 104, 90479052. 